\title{
<应例報告 $>$
}

\section{女性ホルモン剤によると思われる \\ 肝 nodular hyperplasia の一症例}

\begin{tabular}{|c|c|c|c|c|}
\hline 藤井 & ちよ & 辻岡 & 悦二 & 武輪 \\
\hline 湯川 & 進 & 野本 & 拓* & 長崎 \\
\hline
\end{tabular}

要 旨：約 2 年半の間，女性ホルモン剤投与を受け，著明な肝の nodular hyperplasia を来たし た症例を経験した．患者は25歳の女性で, 肝は右季肋下 3 横指触知し, 肝シンチグラム及び腹腔 動脈造影にて異常所見が得られたが，肝機能検查は全く正常であり， $\alpha$-Fetoprotein あ陰性であ った. 試験開腹にて腫瘤は右葉下面に発生し左葉下面に達しているのが確認された。組織学的に は, liver-cell hyperplasia であり, 悪性所見はなく, 電顕像では, 粗面小胞体の増加と, グリコ ーゲンの豊富なことが特徽的であった。

索引用語： nodular hyperplasia 肝細胞腺腫 女性ホルモン 経口避妊薬

\section{はじめに}

従来, 良性の肝腫瘍は非常に稀なるのとされて来た が，1973年 Baum ら”が，経口避妊薬によると考学られ る肝腫瘍の発生例 7 例を報告して以来, 同様の症例報告 が,ことに欧米に扎いて最近相次いでいる. 今回我々 は，肝腫瘤の原因として，女性ホルモン剂の作用を推測 するに至った一应例を経験したので報告すると共に，従 来の報告例之併世，若干の考察を加えてみた。

\section{症例}

患者 : 25歳, 女性, 農業.

\section{主訴 : 肝腫の精查}

初診 : 昭和51年 2 月 7 日

家族歴：伯父；胃癌にて死亡，母; 出産時死亡.

既往歴 : 黄疾, 輸血の既往なし. 昭和47年 4 月, 妊娠 4 カ月で切迫流産となり入院加療したが 8 カ月で早産. その後, 基礎体温が一相性であることを指摘され，昭和 47 年末ょり約 2 年間chlomiphene citrate, chlormadinone acetate, pregnant mare serum, human menopausal gonadotropin, human chorionic gonadotropin 等の投与を

$\begin{array}{rll}* & \text { 和歌山県立医科大学代謝内科 } \\ * * & \text { 同 } & \text { 消化器内科 } \\ * * * & \text { 同 } & \text { 消化器外科 } \\ * * * * & \text { 同 } & \text { 第一病理学教室 }\end{array}$

受けた。

現病歴: 昭和51年 1 月，左下歯肉聥脹のため近医受診 し，たまたま肝隀大を指摘された。肝機能検查で異常な く，精查のため当科受診. 自覚症状は注とんど認めてい ない.

初診時所見：体格中等度. 栄養状熊良. 皮庯正常. 眼 眕結膜に貧血なく、眼球結膜に黄瘨を認めない、リンパ 腺腫脹なく，胸部打㯖診にても異常なし. 腹部では, 肝 を右季助下 3 横指触知. 脾, 腎は触れず. 腹水認めず.

下肢に浮腫なし. 神経学的異常なし.

臨床㭘查成績：Table 1亿示すごとく，肝機能検查は 正常で， $\alpha$-Fetoprotein も陰性であった．ただ末梢血で 好酸球が15 30\% と增加し, 骨䯣でも，好酸球系が14.8 \%と高値を呈したが，IgE，一般吸入抗原及び 奇生虫抗 原に上る皮内反応，便虫卵，父親の好酸球数には異常は 見られず.この好酸球增多は，薬剤使用に対する反応性 の増加であろらかと思われる.胸部 $\mathrm{X}$ 線, 食道, 胃, 大晹 透視，及び胆裹造影で異常所見なし. 腹部単純 $\mathbf{X}$ 線で。 腸管ガス像の左下方への著明な压排あり，腹䑤動脈造影 では，肝動脈右枝の全般的な伸張が指摘されたが，肝エ コーでは腫煌エコーは見られず.肝ンンチグラムでは， 肝右葉の腫大と脾の描出をみとめ, 右葉上部と左葉に cold area を疑わしめた (Fig. 2a).

腹腔鏡検査 : 肝右葉下面に腫湯の存在がみとめられ， 
Table 1. Laboratory Data

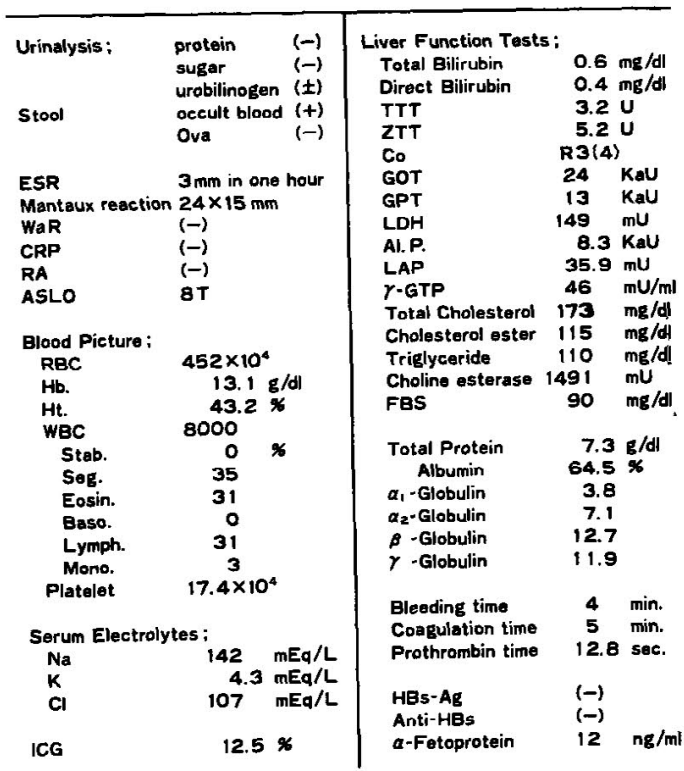

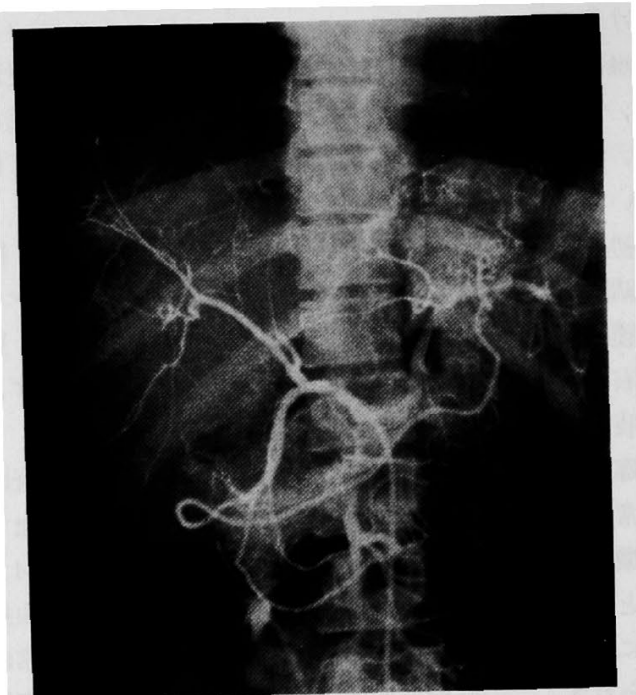

Fig. 1 Celiac angiography demonstrates stretching of right hepatic arteries. No shadow of tumor-like region is seen.

肝生㭘の結果, 組織学的に, liver-cell hyperplasia の所 見を得たが，原因不明のまま試験開腹を実施した。

試験開腹所見 (Fig.3) : 肝右葉は高度に腫大し, 表面 に軽度の凹凸をみとめ，所々にフィブリンの析出を見 た。しかし肝硬变の所見はなかった。稙瘤は右葉下面よ

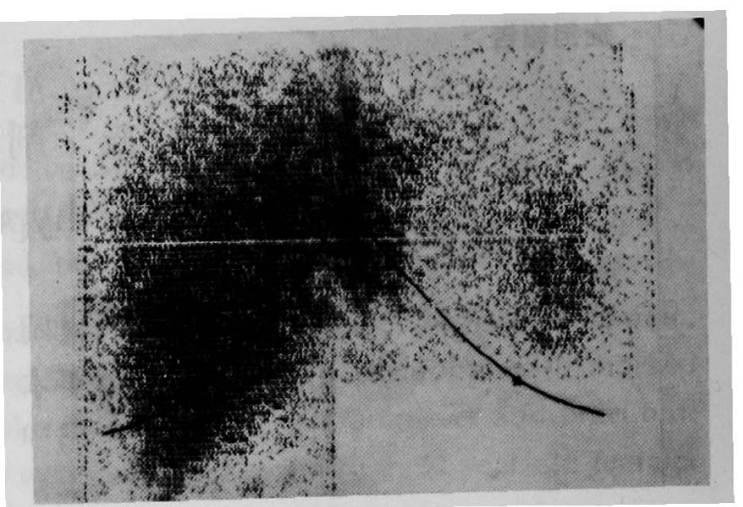

Fig. 2a Scintigram of the liver and spleen on March 9, 1976. Swelling of the right lobe, cold area of the left lobe and slightly increased uptake of the spleen are seen.

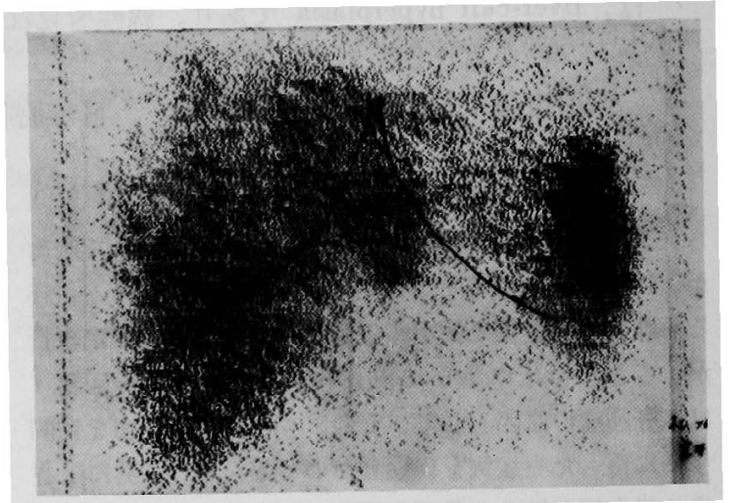

Fig. 2b Scintigram of the liver and spleen on April 21, 1976. Note more decreased uptake of liver and increased uptake of spleen than Fig. 2a.

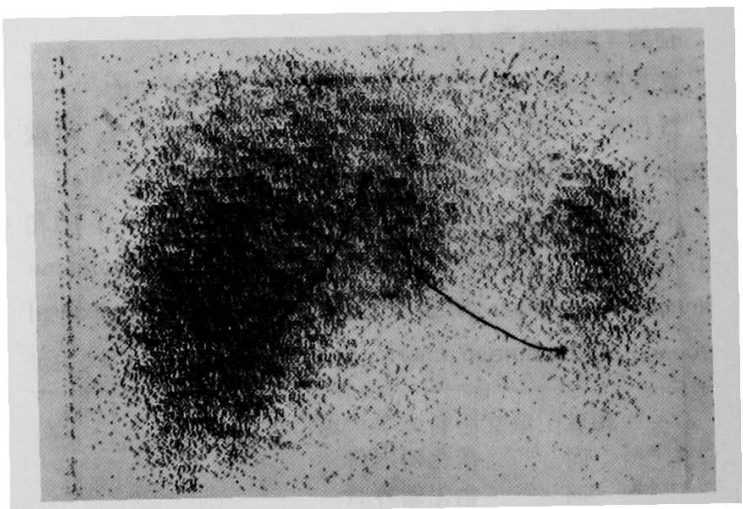

Fig. 2c Scintigram of the liver and spleen on February 16, 1977, shows same pattern as Fig. 2a. 


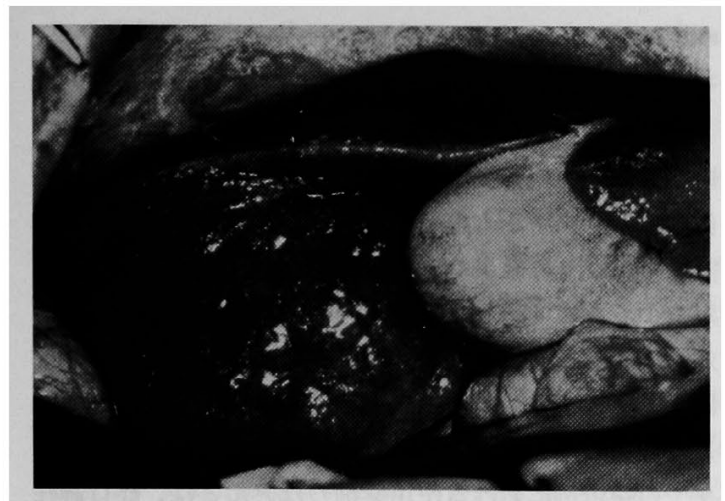

Fig. 3 Intraoperative appearance of mass in right lobe of liver.

り発生し左葉下面へ達していた．正常肝との境界はほぼ 明膫で, 腫瘤の表面は顆粒状〜(乃至)小結節状を呈し, 色 調は正常部とほとんど差がなく，硬度は正常部にくらべ やや增していた，腫瘤部穿刺にては，少量の血液を採取 されたのみで内容液なく, cyst の存在は否定された.門 脈は腫瘤により臣迫気味であり, 脾はやや尰大し, 少量の 腹水を認めた。以上により腫陽は充実性かつ良性であろ うと考えられたが, 切除は不能であり, Silverman 生検 針による biopsy と, wedge biopsy のみにとどまった。

臨休経過：入院中一時, 腹水が出現したが利尿剂短期 間投与で消失した. 現在, 通院にて 経過観察中である か，䀒隀の大ささ，血液検查等に变化は見られず， $\alpha-$ Fetoprotein は52年 1 月は $24 \mathrm{ng} / \mathrm{ml}, 5$ 月は $5.69 \mathrm{ng} / \mathrm{ml}$ で あった. 肝シンチでは, 51年 4 月, 前回のシンチにくら ベ, 肝全体の取り込みが不規則に低下し, 脾一の取り込 みが增加しており (Fig. 2b), 病変の進行を推測せしめ たが，その後の肝シンチでは著明な変化は見られていな W(Fig. 2c).

Wedge biopsy の所見

光顕所見 : 肝の小葉構造はよく保たれているが, Glisson 鞘には微細な結合織性の線維の増生があり，そのた めに Glisson 輎の拡大が軽度にみられた。しかし同部へ の細胞浸潤や，肝小葉の切り崩し現象は認められなかっ た. 肝小葉内には, 細胞索が著しく乱れた明るい胞体を 持つ大きな肝細胞が 結節状に堌生しているのが見られ た (Fig. 4).この肝細胞には，核の大小不同，染色性 の差などの変化は双られず, 又異型性るみられなかっ た. しかし 2 核を持つ細胞 (矢印) が目立っていた (Fig. 5).これらの細胞に fatty change とか cell necrosis は みられなかった。結節状に増生せる肝細胞の 周辺部に

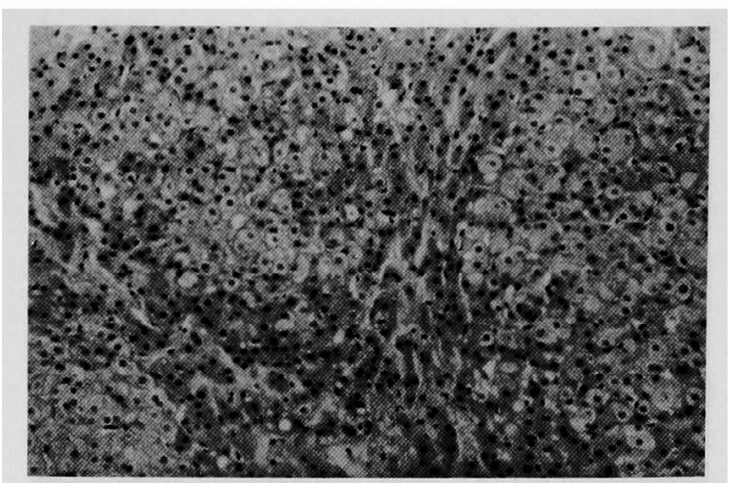

Fig. 4 Note focal nodular hyperplasia of liver tissue obtained from needle biopsy st exploratory laparotomy. (H.E. $\times 100)$

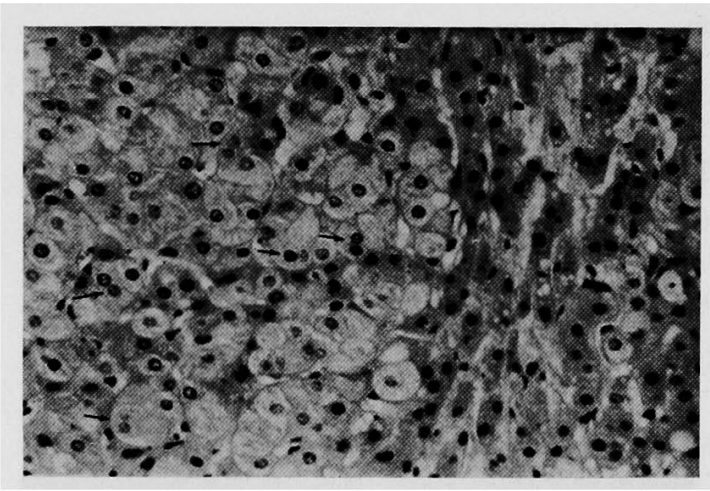

Fig. 5 Note large hepatocyte with abundant cytoplasm, as seen in Fig. 4. No cellular atypism, but many double nucleoid cells are seen (arrows). (H.E. $\times 200)$

は，圧迫された肝細胞が索状にみとめられ，一部には中 心静脈が存在した。

Azan-Mallory 染色では, それらの場所に未だ fibrosis や capsule の形成はみとめられなかったが，鍍銀線維 の膠原化が進んでいるような印象を与皇た (Fig. 6). peliosis hepatis や, 肝硬変さらに, hepatoma を示嘫す る所見はみられなかった。

電顕所見：電子顕微鏡による肝細胞の変化は主に細胞 質にみられた．Fig. 7,8 にみられるように，腫大した 肝細胞質内には，短くらぎれた粗面小胞体の増生がとく に羿められ，それらにましって豊富な glycogen granule と一部で大小不同, 変形を示す mitochondria をみとめ た. 他の organella に目立った変化はなく, 又 ductule の microvilli にも変化はみられなかった. 核内の chro- 


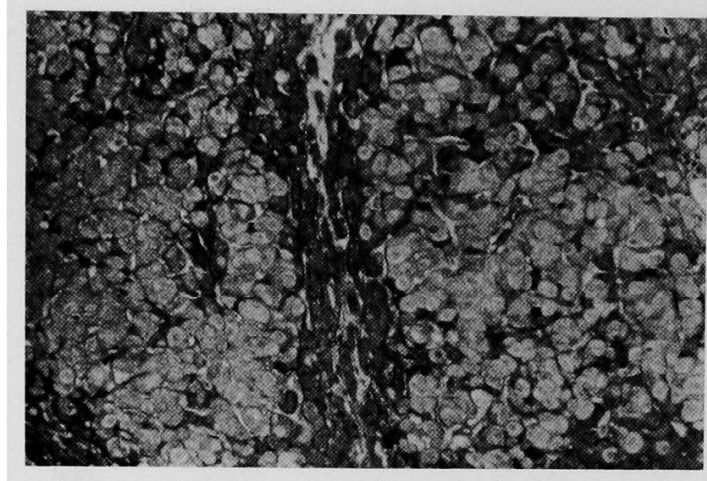

Fig. 6 note foci of nodular hyperplasia compress other liver cells, but no fibrosis and no encapsulation are seen. (Mallory-Azan $\times 200$ )

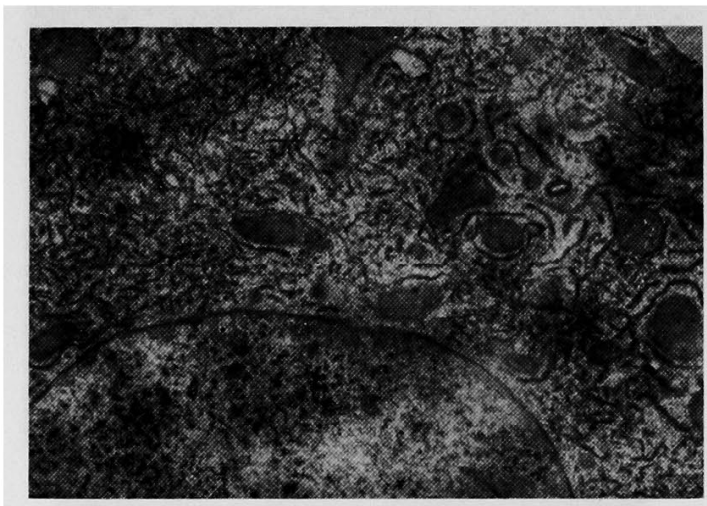

Fig. 7 Note abundant flattened and shortened r-ER and various sized mitochondria are seen under electron microscopy. $(\times 17,000)$

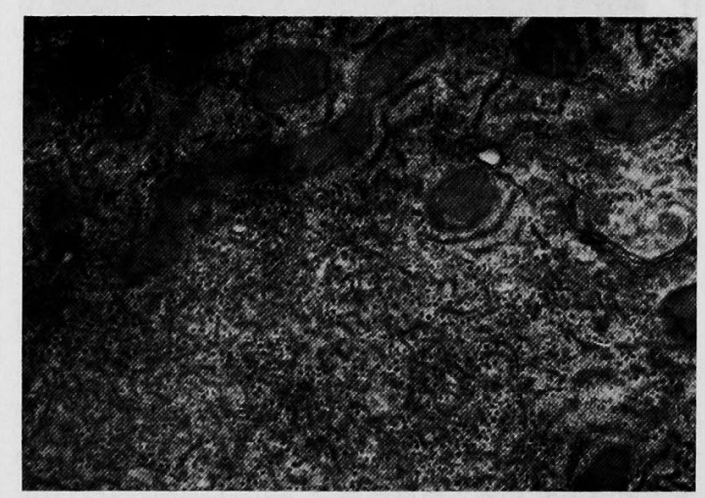

Fig. 8 This picture illustrates the proliferative r-ER and rich glycogen granules of the hyperplastic hepatocytes. $(\times 31,000)$ matin pattern は，ほぼ正常であった.

考 案

Baumら ${ }^{1)}$ の報告以来, 経口避妊薬服用之肝腫渴発生 に関する症例報告は 100 例を越光ている.この最近の症 例増加の意味するむのは，単にこのような症例に対する 関心の高まりの結果のみならず，両者の因果関係を強く 示唆するものである．経口避妊薬を止めると尰瘍の縮小 が見られること，腫瘍切除後さらに経口避妊薬を领み続 けると，再び腫㻛の発生を見たといら報告も，両者の関 連性を裏つ゚けるすのとして興味深い2)。このように現在 までの報告例に和ける使用薬郕のほとんどは，経口避娃 薬, 即ち合成 estrogen と progestogen の合剤であるが, 我々の症例のごとき不妊治療例”， premarin 長期使用 例，出産直後のもの等が報告されている. Nissen ら"は， 経口避娃薬によると考光られる67例住つき臨床的統計を 行なっている，それによると，発症例は35歳以下が多く，

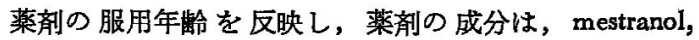
ethinyl estradiol 等の estrogen, norethynodrel, norethindrone, ethynodiol diacetate, norgestrel, dimethisterone, norethisterone, lynestrenol 等の, progestogen $か ゙$ 挙げら

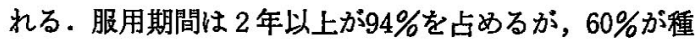
々の薬剂を 5 年以上服用している，症状については，次 の 3 ダループに区別される. (1) 持続的な上腹部痛, 上 腹部腫瘤の自覚または他覚.さらに悪心，呕吐，食思不 振，体重隇少，門脈圧迫などの改候を呈するすの. (2) 腫 瘤の腹琶内破裂により腹膑内出血,ショックをきたして 発見されるもの. (3) 無症候性のもの.この場合は, 他 の腹鲑内手術の際に偶然発見されるるので，この上うな 潜在患者が多数存在する可能性を瞕示している. 術前䛦 断としては,ルーチンの肝機能検查や $\alpha$-Fetoprotein は 特異な值を示さない．肝シンチは的 $75 \%$ に陽性所見を呈 し, Sonography b腫煌が充実性か 震胞かの判別认有用 である. 選択的血管造影は，術前検查としては最もすぐ れたものと思われる. 即ち，畽湯が良性であるか悪性で あるかのある程度の鑑別や，手術計画の一助として役立 つ. 肝生検炕上る組織診断は，一般的にこれらの腫湟か゚ 血管に富むため出血の危険が大きく，禁忌とする意見も ある。治療としては，外科的切除が最良であり，切除し 得た者の予後は非常に良い。このため，たと兄腹壁内出 血を来たしている状態でも，切除出来れば救命できると いう可能性を考慮に入れて，適切な鑑別䛦断をする必要 がある。

これら腫場の組織学的分類は，現在まだ混乱状態にあ 
$\eta$, 症例火より adenoma, hamartoma, focal nodular hyperplasia (以下 FNH) 等と報告されている. McAvoy $^{5)}$ は adenoma と FNH の相違点について次のように 述べている. hepatic cell adenoma は, ほぼ encapsulation されており，その中に ductule はみとめられない。 肝細胞索は nodularity を示さず，肝細胞中の glycogen は正常かやや増加している. 一方 FNH は, 正常肝と の境界は割合明暸であるが， encapsulation はなく， ductule は尚, 存在している.肝細胞索は nodularity を 示し，その周辺部あるいは septa には大きな血管が存 在する。また肝細胞には多量の glycogen が含まれると されている. 本症例では fibrosis や capsule の形成はみ られず，結節状に堌生した肝細胞には ductule がみとめ られ，压迫された肝細胞の一部に，なお Glisson 鞘の存 在がみられた. 肝細胞中の glycogen は非常に増加して おり，又残存肝に cirrhosis 所見はみられなかった。 以 上の所見から McAvoy の criteria に従らと本例は FNH と考えるのが妥当と思われる.

本症例では，肉眼的に大きな腫湯形成をみたが，これ は生検肝組織で見られるよらな FNHがより集まって， このように腫大したあのであると考えられる.このよら な FNH は，今後す増生を続け，さらに大きな単一の nodular hyperplasia あるいは adenoma の形成へと進展 していく可能性すあると思われる. 現在, 本症例では, 今まで使用していた女性ホルモン剤の投与を中止し，释 過観察中であるが，果してこれらの FNH が今後，どの よらな経過をとるか，はなはだ與味ある所である。

一方，組蟣の相違による切除適応，予後についても， 色々な意見が述べられている.放置した場合，覀性化の 有無が最大の問題となる. Davis $5^{67}$ は悪性化を来たし た症例を報告しているが，hepatocellular carcinoma 発 生の報告32 が数例あることも事実である。

以前より androgenic anabolic steroid は, primary hepatocellular carcinorna を induce する可能性が指摘 されている゙が，最近肝の adenoma FNH など良 性腫湢を莣起することも知られて来た。合成 estrogen ๖ progestogen む17 $\alpha$-alkylated 19-nor steroid である 点 anabolic steroid の構造式に類似し，また anabolic steroid は黄疸, 胆计らっ滞, peliosis hepatisなどを来 たすが，合成 estrogen, progestogen 服用によっても同 様な変化が引き起こされることが知られだ)。

Perez ら9)は，経口避妊薬服用症例の肝組織を検討し た結果, 電顥で, 服用 $1 \sim 6$ カ月の群に滑面小胞体の増
加. 服用12 30カ月の 群に mitochondria の変形, 尰 大，硝子体様封入物をみとめている。また progestogen は, chlormadinone acetateを除いて, すべて ALAsynthetase inducing activity を持つことが証明されて括 $\eta^{10)}$ この形態と機能の変化を結びつけて, progestogen は滑面小胞体の薬物代謝系に 影響することが考えられ る。

以上の胆汁うっ渔作用および䣼素誘導作用から次のよ らな仮説る立てられている(1). 即ら「経口避妊薬服用婦 人に見られる subclinical cholestasis の存続は，様々な 物質の胆汁への分泌阻害を意味し, この際もちろん服用 したステロイドの分必も阻害される.こうして肝内に蓄 積した progestogen は，その酵素誘導作用により，ある 種の compound を toxic metabolite へと変化させること によってそれらの発癌性を発揮させる可能性がある」 ${ }^{12)}$ と.

一方 estrogen については, 少量でラット肝の再生を 来たすこと，即ち粗面小胞体に影響して蛋白合成に 変 化を与える゙. 。た estrogen は，現在までに，breast， vagina 等の器官におけるる発癌性が明らかにされている. その上 estrogen の持つ thrombogenic action ${ }^{13)} に よ り$ 形 成された病変部が，肝組織の過形成として反応するとい ら意見もある・

1972年 Committee on safety of medicine ${ }^{14)}$ は, 次の ような実験報告を提出した。なラットに norethymodrel, norethisterone, norethisteron+mestranol を投与し, 오 ットに megestrol を投与すると, liver cell tumor の 発生増加が見られた。しかしマウスでは，3系につき 試みたが，字早にかかからず発生頻度は低かった。 hepatoma 自然発生系の $\mathrm{C}_{3} \mathrm{H} / \mathrm{fB}$ 系マウスに norethynodrel+mestranol を投与しても hepatoma の発生は期待 される频度より低かったという．また大量服用による estrogen/progestogen 比がミラットの朋に dose-related oncogenic effect を持つとしている.

一方, Beaconsfield ${ }^{15}$ らは, 下垂体の变化を観察し， 相対的な好酸性細胞の增加, 核の増大, 脱顆粒, ゴシ 体の増大を指摘している。この好酸性細胞は, prolactin cell の可能性が高くこの変化は prolactin cell の hyperfunction を示していると考えられる.

我々は，肝に女性ホルモンリセブターが皆無に等しい ことから，女性ホルモンの肝作用は， prolactin リセプ ターの增加とそれによる prolactin の肝作用の增大, さ らには甲状腺ホルモンの作用る加味されているのではな 
いかと推测している。

\section{結 語}

長期にわたる女性ホルモン剤使用によって生じたと思 われる肝の nodular hyperplasia の一症例を報告した. 女性ホルモン風と肝腫瘍発生との関連については，さま ざまな議論があるが，その臨床および実験データは，ま た不十分な段階にあり，今後の詳細な検討が必要と思わ れる. 同時に，経口避妊薬を始めとするこの種のステロ イドホルモン剤の使用にあたっては十分な注意が望まれ る。

\section{文献}

1) Baum, J.K. et al.: Possible association between benign hepatomas and oral contraceptives. Lancet, 2: 926-929, 1973.

2) Stauffer, J.Q. et al.: Systemic contraceptives and liver tumors. Annals of internal medicine, 85 : 122-123, 1976.

3) Thalassinos, N.C. et al.: Liver-cell carcinoma after long-term estrogen-like drugs. Lancet, I: 270,1974 .

4) Nissen, E.D. et al.: Association of liver tumors with oral contraceptives. Obstetrics and Gynecology, 48: 49-55, 1976.

5) McAvoy, J.M. et al.: Benign hepatic tumors and their association with oral contraceptives. Arch. Surg., III: 761, 1976.

6) Davis, M. et al.: Histological evidence of carcinoma in a hepatic tumor associated with oral contraceptives. British Medical Journal, 4: 496-498, 1975.
7) Johnson, F.L. et al.: Association of androgenicanabolic steroid therapy with development of hepatocellular carcinoma. Lancet, 2: 12731276, 1972.

8) Adlercreutz, $H$. et al.: Some aspects of the interaction between natural and synthetic female sex hormones and the liver. Am. J. Med., 49: 630-648, 1970.

9) Perez, V. et al.: Oral contraceptives: Longterm use produces fine structural changes in liver mitochondria. Science, 165: 805-807, 1969.

10) Rifkind, A.B. et al.: Induction of hepatic $\delta$-aminolevulinic acid synthetase by oral contraceptive steroids. J. Clin. Endocr., 30: 330$335,1970$.

11) Stanley Goldfalb: Sex hormones and hepatic neoplasia. Cancer Research, 36: 2584-2588, July 1976.

12) Lingeman, C.H.: Liver-cell neoplasms and oral contraceptives. Lancet, I: 64, 1974.

13) Gillett, M.P.T. et al.: Oral contraceptives, plasma-lysolecithin and platelet aggregation. Lancet, 2: 1387-1388, 1974.

14) Committee on Safety of Medicines. Carcinogenicity tests of oral contraceptives. HMSO, London, 1972.

15) Beaconsfield, P.: Liver tumors and steroid hormones. Lancet, I: 516-517, 1974. 


\title{
A Case of Focal Nodular Hyperplasia of the Liver Associated with Female Sex Hormone Treatment
}

\author{
Sachiyo FujII, Etsuji TsujIoka, Mitsuo Takewa, Susumu Yukawa, \\ Hiroshi Nomoto*, Yasuhiko NAGASAKI**, Yuzo OHSAWA*** and \\ Tomoyuki TANAKA***
}

In this report, we proposed a case of a 25 -year-old woman with large tumor of the liver. For approximately two years she received female sex hormones and other drugs to treat threatened abortion and to prevent infertility.

On laboratory examination liver function tests were normal: $\alpha$-fetoprotein was negative, but hepatic scintigram revealed enlargement of the right hepatic lobe with presumable cold areas and enlarged spleen. Exploratory laparotomy showed a large hepatic tumor which had developed from the underside of the right hepatic lobe and extended to the underside of left the lobe. It appeared to be massive and benign, but was not excisable; only biopsies were taken. Biopsies yielded histological findings of focal nodular liver-cell hyperplasia, not an adenoma.

We suggested that female sex hormone may contribute to the liver-cell hyperplasia development. And, in view of the virtual absence of female hormone receptors in the liver, the hepatic action of female hormones may consist of an increase in prolactin receptors, a resultant increase in the hepatic action of prolactin, and also the effect of thyroid hormone.

\footnotetext{
- Department of Internal Medicine (Metabology), Wakayama Prefectural University of Medicine (Wakayama)

** Department of Internal Medicine (Digestive System), Wakayama Prefectural University of Medicine (Wakayama)

*** Department of Surgery (Digestive System), Wakayama Prefectural University of Medicine (Wakayama)

**** 1st Department of Pathology, Wakayama Prefectural University of Medicine (Wakayama)
} 